\title{
Hubungan Aktivitas Fisik, Konsumsi Cairan, Status Gizi Dan Status Hidrasi Pada Pekerja Proyek
}

\author{
Ferlica Pustisari ${ }^{1,}$ Laras Sitoayu $^{2 *}$, Rachmanida Nuzrina ${ }^{3}$, Dudung Angkasa ${ }^{4}$, Nazhif Gifari ${ }^{5}$ \\ 1,2,3,4,5 Program Studi S1 Ilmu Gizi FIKES Universitas Esa Unggul \\ laras@esaunggul.ac.id
}

\begin{abstract}
Hydration status is a condition that describes the amount of fluid in the body. If the intake of fluids from food and drinks in the project workers is not met, then it has an opportunity to cause dehydration. Declining productivity in workers can be caused by dehydration.

Objectives this study to determine the relationship between physical activity, fluid intake, nutritional status and hydration status in project workers. An observational study with a cross sectional approach, the study population was project workers. The number of samples in this study were 53 respondents. The study was conducted by direct interview, measurement of body weight, height, body fat percent and urine specific gravity. Data analysis in this study used the Spearman correlation test.

The age of workers ranged from 17-52 years. The average BMI score was $22,417 \mathrm{~kg} / \mathrm{m} 2$. The average value of PAL 2.37. The average fluid intake was $2018.30 \mathrm{ml}$. Moyority of workers have hydration status in severely dehydrated group (79.2\%.) There is a relationship between physical activity (0.026), fluid intake and hydration status (0.001) but there is no relationship between nutritional status and hydration status (0.789).
\end{abstract}

Keywords: fluid intake; nutritional status; physical activity; hydration status. 


\section{PENDAHULUAN}

Demi tercapainya produktivitas dalam kerja yang maksimal maka tenaga kerja berhak mendapatkan jaminan kesehatan dan keselamatan kerja (UU RI no 13 Tahun 2003, 2019). Status kesehatan serta produktivitas pada pekerja ditentukan berdasarkan keseimbangan beban dari pekerjaan dan beban dari lingkungan pekerjaan (Suprabaningrum \& Dieny, 2017). Seiring dengan bertambahnya jumlah tenaga kerja yang ada di Indonesia masalah kesehatan pada pekerja harus diperhatikan, kecukupan cairan merupakan salah satu faktor kebutuhan gizi pada pekerja (Malisova et al., 2016). Tubuh manusia dapat menghasilkan panas tubuh untuk menjaga fungsi organ. Tempat, durasi dan jenis aktivitas menentukan panas tubuh.

Pekerja proyek merupakan tenaga kerja yang bekerja di lingkungan terbuka dengan temperatur udara di Tangerang $32^{\circ} \mathrm{C}$, dalam durasi cukup lama sehingga menyebabkan terjadinya kekurangan asupan cairan, hal itu disebabkan karena adanya pengeluaran cairan secara berlebih, namun masalah ini sering kali diabaikan dan mempunyai pengaruh terhadap gangguan kesehatan kerja, salah satunya dehidrasi. Dampak dari dehidrasi adalah infeksi saluran kemih._Kinerja pada pekerja dapat menurun karena mengalami dehidrasi (Suprabaningrum \& Dieny, 2017). Mulut kering, konsentrasi berkurang, rasa ngantuk serta kesemutan hingga mati rasa merupakan dampak lain dari gejala dehidrasi. Dehidrasi adalah kurangnya pengganti asupan cairan untuk memenuhi kebutuhan karena pengeluaran cairan yang berlebih (Ramadhan \& Rismayanthi, 2005). Meskipun tidak melakukan kegiatan terdapat cairan tubuh yang dikeluarkan sebanyak 5\%-10\% setiap hari. Setiap harinya cairan dalam tubuh akan berkurang sekitar 5\%-10\% meskipun tidak berkegiatan. Untuk menghindari terjadinya ketidakseimbangan cairan harus diimbangi dengan kebutuhan asupan cairan_(WHO, 2004).

$$
\text { Hidrasi adalah keseimbangan }
$$
antara asupan dan pengeluaran cairan pada tubuh. The Indonesian Hydration Regional Study (THIRST) menunjukkan kurangnya asupan cairan kategori ringan terdapat pada orang dewasa (45.5\%) (Iman, Budi. S; Hardinsyah; Siregar, Parlindungan; Pardede, 2011). Pada penelitian ini menunjukkan bahwa dari seluruh sampel, hanya sebanyak 28,8\% 
pada pekerja yang status hidrasinya baik. Lainnya menunjukkan_dehidrasi kategori ringan sebanyak $37 \%$ dan dehidrasi sedang sebanyak 15,1\%):_Asupan cairan penting untuk memenuhi kebutuhan tubuh. Dari berbagai rujukan, terdapat variasi rekomendasi kebutuhan cairan pada orang dewasa. Hal ini kemungkinan disebabkan karena_perbedaan_komposisi tubuh, aktivitas fisik yang dilakukan, banyaknya asupan cairan, serta lingkungan kerja (Iman, Budi. S; Hardinsyah; Siregar, Parlindungan; Pardede, 2011). Penelitian lain menunjukkan hubungan IMT dan asupan cairan dari total asupannya pada orang dewasa (Kant et al., 2009).

\section{Dehidrasi dapat terjadi karena} peningkatan aktivitas yang tidak diimbangi dengan asupan cairannya, hal tersebut memiliki peluang untuk terjadinya dehidrasi. Aktivitas fisik merupakan aktivitas dari waktu kerja dan waktu luang, yang membutuhkan tenaga dari tubuh. Pengeluaran urin, feses merupakan aktivitas sel. Lambung dapat menampung penggantian cairan yang dikeluarkan lebih lambat daripada cairan yang dikeluarkan melalui keringat pada saat terjadinya peningkatan aktivitas (Diyani, 2012).
Berdasarkan latar belakang maka penelitian ini dilakukan untuk menganalisis hubungan aktivitas fisik, asupan cairan, dan status gizi dan status hidrasi pekerja proyek, pengukuran status hidrasi berdasarkan hasil pengukuran metode berat jenis urin (BJU) pada pekerja proyek Apartemen.

\section{METODE PENELITIAN}

Jenis penelitian ini adalah observational dengan pendekatan crosssectional. Penelitian ini dilakukan di proyek artemen pada bulan Oktober 2019.Pekerja proyek dan bersedia menjadi responden penelitian dengan mengisi formulir informed consent termasuk dalam kriteria inkulusi. Kriteria eksklusi sampel pada penelitian ini adalah pekerja yang hadir tetapi tidak bersedia ikut dalam penelitian, menderita penyakit kronis, sedang diare, sedang mengonsumsi obatobatan atau vitamin. Data identitas mencakup tanggal lahir, nama, usia dan nomor telepon. Data identitas didapat dengan wawancara yang menggunakan formulir identitas responden. Data recall aktivitas fisik didapat melalui wawancara langsung dengan menggunakan formulir physical activity recall 2x24 jam yang berisi jenis dan durasi dalam beraktivitas. Data recall asupan cairan diperoleh melalui wawancara secara langsung 
dengan formulir food recall $2 \times 24$ jam.

Data status gizi diperoleh melalui pengukuran berat badan, tinggi badan dan persen lemak tubuh menggunakan BIA. Data untuk status hidrasi didapat melalui pengecekan urin dengan cara mencelupkan urin ke wadah menggunakan dipstick urine dan didapat Berat Jenis Urin (BJU) untuk mengetahui status hidrasi.

Pengambilan sampel penelitian diperoleh dengan cara total sampling dan didapatkan sampel sebanyak 53 pekerja proyek. Analisa data pada penelitian ini terdiri dari analisa univariat dan analisa bivariat menggunakan uji spearman. Ethical Clearance didapat dari"Komisi Etik Penelitian Universitas Esa Unggul untuk penelitian ini dengan Nomor : 050819.503/DPKE-KEP/FINALEA/UEU/XI/2019”.

\section{HASIL DAN PEMBAHASAN}

\section{Karakteristik Responden}

Responden dalam penelitian ini merupakan pekerja proyek yang berjumlah 53 orang. Gambaran usia, IMT, aktivitas fisik, asupan cairan dan persen lemak tubuh pekerja proyek apartemen dapat dilihat pada Tabel 1 di bawah ini:
Tabel 1. Gambaran Variabel Penelitian

\begin{tabular}{lc}
\hline \multicolumn{1}{c}{ Variabel Penelitian } & Rerata \pm SD \\
\hline Usia (tahun) & $33.75 \pm 8.458$ \\
IMT $\left(\mathrm{kg} / \mathrm{m}^{2}\right)$ & $22.417 \pm 2.5600$ \\
Aktivitas fisik (kkal/jam) & $2.37 \pm 0.008$ \\
Asupan cairan $(\mathrm{ml})$ & $2018.30 \pm 683.036$ \\
Persen lemak tubuh $(\%)$ & $18.474 \pm 4.1979$ \\
\hline
\end{tabular}

Berdasarkan Tabel 1, dapat diketahui bahwa rata-rata usia pekerja adalah $33.75 \pm 8.458$ tahun, artinya sebagian besar pekerja masuk pada usia dewasa. Sedangkan untuk IMT pekerja yaitu dengan rata-rata $22.417 \pm 2.5600$ $\mathrm{kg} / \mathrm{m}^{2}$, yang artinya masih pada kategori status gizi baik. Untuk aktivitas fisik pekerja tergolong aktivitas fisik berat dengan rata-rata $2.37 \pm 0.008$ hal ini dapat dilihat dalam kegiatan sehari-hari para pekerja bekerja di proyek banyak melakukan angkat berat. Asupan cairan pekerja dengan rata-rata $2018.30 \pm 683.036$ $\mathrm{ml}$ dimana jumlah ini masih dibawah asupan anjuran. Persen lemak tubuh pekerja normal cenderung rendah_dengan rata-rata18.474 $\pm 4.1979 \%$.

\section{Gambaran Status Hidrasi Pekerja Proyek Apartemen}

Keseimbangan cairanberfluktuasi secara terus-menerus dan adanya cairan yang dikeluarkan (Meyer et al., 2012). Status hidrasi menggambarkan total cairan 
yang terdapat di dalam tubuh. Gambaran status hidrasi pekerja proyek Apartemen dapat dilihat pada Tabel 2 di bawah ini :

Tabel 2. Gambaran status hidrasi pekerja proyek Apartemen

\begin{tabular}{lcc}
\hline $\begin{array}{l}\text { Tingkat } \\
\text { Hidrasi }\end{array}$ & n & \% \\
\hline Dehidrasi Berat & & \\
Dehidrasi & 42 & 79.2 \\
Sedang & 3 & 5.7 \\
Dehidrasi & 8 & 15.1 \\
Ringan & & \\
\hline
\end{tabular}

Berdasarkan Tabel 2, dapat diketahui bahwa status hidrasi pekerja di proyek Apartemen_mengalami dehidrasi berat 42 orang $(79.2 \%)$, dehidrasi dengan kategori sedang sebanyak 3 orang $(5.7 \%)$ dan dehidrasi ringan 8 orang $(15.1 \%)$. Hasil penelitian ini memperlihatkan bahwa pekerja yang dehidrasi berat lebih tinggi daripada pekerja dengan dehidrasi sedang dan ringan.

\section{Hasil Analisis Aktivitas Fisik, Asupan} Cairan, Status Gizi dan Status Hidrasi

Analisis yang digunakan dalam penelitian ini adalah uji Spearman dengan data yang tidak normal. Hasil analisis dapat dilihat pada Tabel 3 di bawah ini :
Tabel 3. Hasil Analisis Aktivitas Fisik, Asupan Cairan, Status Gizi dan Status Hidrasi

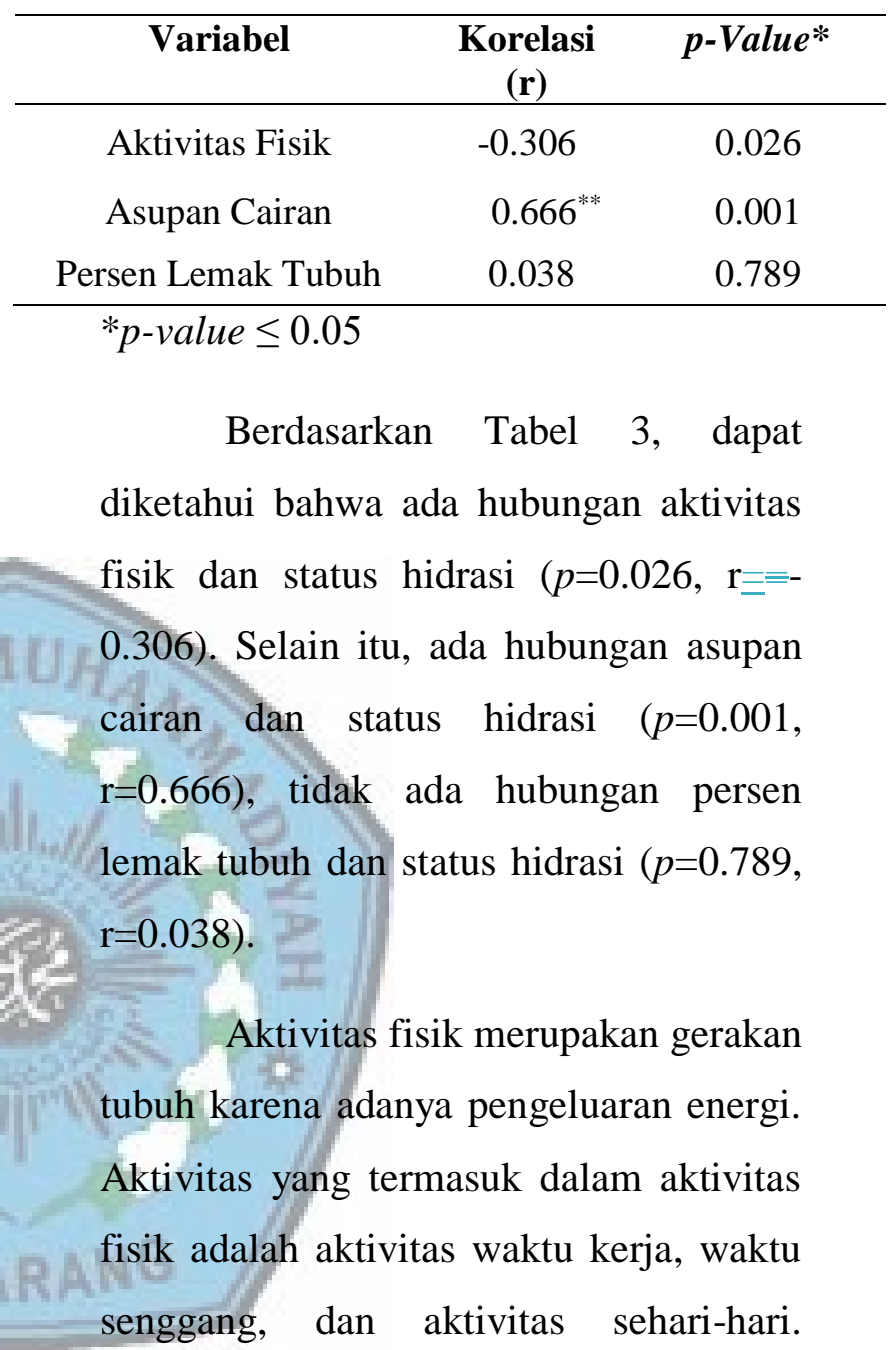
Aktivitas fisik merupakan aktivitas dari waktu kerja dan waktu luang, yang membutuhkan tenaga dari tubuh.

Aktivitas dalam penelitian ini adalah aktivitas yang dilakukan oleh responden selama $2 \times 24$ jam pada hari kerja. Aktivitas fisik yang telah dilakukanresponden lalu di konversi menjadi nilai PAL dan dikategorikan menjadi aktivitas berat (2.00-2.40), 
aktivitas sedang (1.70-1.99), dan aktivitas ringan (1.40-1.69) (WHO/FAO, 2002).

Hasil dari penelitian ini menunjukkan bahwa ada hubungan aktivitas fisik dan status hidrasi pekerja proyek apartemen $(p=0.026$ dan $r=-0.306)$ berarti memiliki hubungan lemah dengan arah negatif. Hal tersebut terjadi karena konsumsi cairan belum tercukupi dan tidak dapat memenuhi kebutuhan cairan di dalam tubuh. Namun, baik aktivitas berat atau tidak, keduanya memiliki peluang terhadap terjadinya dehidrasi. Hasil ini searah dengan Briawan (2011) mengatakan ada hubungan aktivitas fisik dan status hidrasi (0.001).

Berbagai fungsi asupan cairan diperlukan oleh tubuh untuk mengatur suhu tubuh, zat pelarut dan pembentukan sel (Iman, Budi. S; Hardinsyah; Siregar, Parlindungan; Pardede, 2011). Konsumsi cairan dapat berupa asupan cairan yang berasal pada saat makan dan minum (Andayani, 2013). Pekerja dalam lingkungan panas memiliki peluang mengalami tekanan panas, pengganti cairan yang tidak cukup memiliki risiko dehidrasi. Hal tersebut akan terjadi karena pengeluaran banyak cairan di dalam tubuh.
Konsumsi cairan dapat diketahui berdasarkan food recall 2x24 jam. Konsumsi cairan dapat berupa asupan cairan yang berasal pada saat makan atau minum (Andayani, 2013). Pekerja dalam lingkungan panas memiliki peluang mengalami tekanan panas, penggantian cairan yang tidak cukup memiliki risiko untuk terjadinya dehidrasi.

Hasil dari penelitian ini menyatakan ada hubungan asupan cairan dan status hidrasi pada pekerja proyek apartemen $(p=0.001$ dan $\mathrm{r}=0.666)$ yang berarti asupan cairan dan status hidrasi pekerja proyek memiliki hubungan yang kuat arahnya positif berarti semakin meningkat asupan cairan, maka BJU menurun dan status hidrasinya termasuk baik. Hasil penelitian ini searah dengan penelitian lain bahwa ada hubunganasupan cairan dan status hidrasi (0.009)_(Maharani, 2018).

Status gizi berhubungan erat dan berpengaruh pada produktivitas dan efisiensi kerja. Status gizi merupakan keseimbangan asupan zat gizi yang dikeluarkan dari metabolisme keadaan fisik (Almatsier, 2009). Kekurangan asupan cairan merupakan salah satu faktor yang sering dialami oleh pekerja. Pada penelitian ini pengukuran IMT pada pekerja menggunakan BIA (Bioelectrical 
Impedence Analysis) untuk

menggambarkan lemak tubuh karena lebih berkorelasi dengan konsentrasi lipid (Humaera et al., 2017).

Hasil dari penelitian ini menunjukkan tidak ada hubungan status gizi dan status hidrasi pekerja proyek apartemen ( $p=0.789$ dan $\mathrm{r}=-0.38$ ) yang berarti memiliki hubungan lemah artinya, semakin meningkatnya total lemak dalam tubuh maka status hidrasi juga meningkat. Penelitian ini searah tentang status gizi dengan status hidrasi, hasilnya menunjukkan tidak ada hubungan status gizi dan status hidrasi $(0,072)$ (Maharani, 2018)

Tidak adanya hubungan status gizi dan status hidrasi karena kejadian dehidrasi terdapat pada responden yang agak gemuk dengan presentase lemak tubuh $16-20 \%$ sebanyak $47 \%$, tetapi juga ditemukan pada responden yang memiliki IMT normal dengan presentase lemak tubuh $8-15 \%$ sebanyak 26\%. Meskipun tidak ada hubungan dalam penelitian ini, seseorang harus mencukupi kebutuhan cairannya walaupun presentase lemak tubuh seseorang berbeda.

\section{KESIMPULAN DAN SARAN}

\section{Kesimpulan}

1. Ada hubungan antara aktivitas fisik dan status hidrasi.

2. Ada hubungan asupan cairan dan status hidrasi.

3. Tidak ada hubungan status gizi dan status hidrasi

\section{Saran}

1. Disarankan kepada pihak proyek untuk memberikan edukasi terkait pentingnya mengkonsumsi cairan yang cukup selama bekerja dan menyediakan dispenser untuk mempermudah pekerja mengambil minum pada saat bekerja

2. Disarankan kepada pekerja proyek untuk mengkonsumsi makanan yang bergizi dan asupan cairan sebelum bekerja, selama bekerja dan sesudah bekerja.

\section{UCAPAN TERIMAKASIH}

Manuskrip ini telah diikutkan pada Scientific Article Writing Training (SAWT) Batch II, Program Kerja GREAT 4.1.e (Angkasa et al., 2020), Program Studi S1 Gizi, FIKES, Universitas Esa Unggul dengan dukungan fasilitator: Dudung Angkasa, S.Gz, M.Gizi, RD; Khairizka Citra Palupi, S.Gz, MS, RD dan 
Lukman Cahyadi, ST., MM.. SAWT

Batch II juga mendapat dukungan dana dari Universitas Esa Unggul.

\section{DAFTAR PUSTAKA}

Almatsier, S. (2009). Ilmu gizi dasar. PT Gramedia Pustaka Utama, Jakarta.

Andayani, K. (2013). Hubungan Konsumsi Cairan Dengan Status Hidrasi pada Pekerja Industri LakiLaki. Journal of Nutrition College, 2(4), 547-556.

Briawan, D. et al. (2011). Kebiasaan Minum dan Asupan Cairan Remaja di Perkotaan. Jurnal Gizi Klinik Indonesia, 8(1), 36-41.

Diyani, D. A. (2012). Hubungan Pengetahuan, Aktivitas Fisik dan Faktor Lain Terhadap Konsumsi Air Minum pada Mahasiswa FKM UI Tahun 2012. Jurnal Ilmiah Farmasi.

Humaera, Z., Sukandar, H., \& Rachmayati, S. (2017). Korelasi Indeks Massa Tubuh dengan Profil Lipid pada Masyarakat di Jatinangor Tahun 2014. Jurnal Sistem Kesehatan.

https://doi.org/10.24198/jsk.v3i1.13 956

Iman, Budi. S; Hardinsyah; Siregar, Parlindungan; Pardede, S. S. (2011).
Air Bagi Kesehatan. Centra Communications.

Kant, A. K., Graubard, B. I., \& Atchison, E. A. (2009). Intakes of plain water, moisture in foods and beverages, and total water in the adult US population-nutritional, meal pattern, and body weight correlates: National Health and Nutrition Examination Surveys 1999-2006. American Journal of Clinical Nutrition, 90(3), 655-663.

https://doi.org/10.3945/ajen.2009.27 749

Maharani, D. (2018). HUBUNGAN KONSUMSI CAIRAN DAN STATUS GIZI DENGAN STATUS HIDRASI PADA REMAJA DI SMA NEGERI 2 TUBAN

Malisova, O., Athanasatou, A., Pepa, A., Husemann, M., Domnik, K., Braun, H., Mora-Rodriguez, R., Ortega, J. F., Fernandez-Elias, V. E., \& Kapsokefalou, M. (2016). Water intake and hydration indices in healthy European adults: The European Hydration Research Study (EHRS).

Nutrients. https://doi.org/10.3390/nu8040204

Meyer, F., Volterman, K. A., Timmons, B. W., \& Wilk, B. (2012). Fluid Balance 
and Dehydration in the Young Athlete: Assessment Considerations and Effects on Health and Performance. American Journal of Lifestyle Medicine. https://doi.org/10.1177/1559827612 444525

Ramadhan, R. I., \& Rismayanthi, C. (2005). Hubungan Antara Status Hidrasi Serta Konsumsi Cairan Pada Atlet Bola Basket. In Medikora: Vol. $V X$ (Issue April).

Suprabaningrum, A. R., \& Dieny, F. F. (2017). Hubungan konsumsi cairan dengan status hidrasi pekerja di suhu lingkungan dingin. Journal of Nutrition College, 6(1), 76. https://doi.org/10.14710/jnc.v6i1.16 896
UU RI no 13 Tahun 2003. (2019). Ketenagakerjaan. In Kementerian Tenaga Kerja. https://doi.org/10.1017/CBO978110 7415324.004

WHO/FAO. (2002). Food energy methods of analysis aWHO/FAO. (2002). Food energy - methods of analysis and conversion. Fao Food and Nutrition Paper, 93. http://doi.org/ISSN 0254-4725nd conversion. Fao Food and Nutrition Paper. https://doi.org/ISSN 02544725

WHO. (2004). The global burden of disease 2004. Update, World Health Organization. https://doi.org/10.1038/npp.2011.85 